\title{
Comparative Phytochemical investigation and Antioxidant study of Narcicuss tazetta, Nymphaea mexicana zucc. And Indigofera heterantha.
}

\author{
Saba Sabreen *, Mubashir Hussain Masoodi \\ Department of Pharmaceutical Sciences, University of Kashmir, J\&K, India
}

\begin{abstract}
The study was intended to investigate the presence of phytoconstituents in the bulbs of Narcicuss tazetta, flowers of the plant Nymphaea mexicana, and roots of Indigofera heterantha. The present study provides evidence that methanolic extracts of Narcicuss tazetta, Nymphaea mexicana and Indigofera heterantha contain important compounds with marked bioactivity. Maximum phenolic content was observed in Nymphaea mexicana and maximum flavonoid content was observed in extract of Indigofera heterantha.
\end{abstract}

Keywords: Phytoconstituents, Antioxidant, Nymphaea mexicana, Narcicuss tazetta, Indigofera heterantha

Article Info: Received 21 Jan 2019; Review Completed 25 Jan 2019; $\quad$ Accepted 28 Jan 2019; Available online 15 Feb 2019

Cite this article as:

Sabreen S, Masoodi MH, Comparative Phytochemical investigation and Antioxidant study of Narcicuss tazetta, Nymphaea mexicana zucc. And Indigofera heterantha, Journal of Drug Delivery and Therapeutics. 2019; 9(1-s):107-112 DOI: http://dx.doi.org/10.22270/jddt.v9i1-s.2270

*Address for Correspondence:

Saba Sabreen, Department of Pharmaceutical Sciences, University of Kashmir, J\&K, India

\section{INTRODUCTION}

Antioxidants neutralize the free radicals resulting from various biochemical processes in body ${ }^{1}$. A highly refined and complex antioxidant protection system has therefore been developed by human beings to counteract the damage from these free radicals, with both exogenous as well as endogenous mechanisms constituting this system. These include Nutrient-derived antioxidants like ascorbic acid (vitamin C), tocopherols and tocotrienols (vitamin E), carotenoids, and other low molecular weight compounds such as glutathione and lipoic acid, Antioxidant enzymes, e.g. superoxide dismutase, glutathione peroxidase, and glutathione reductase, which catalyze free radical quenching reactions, Metal binding proteins, such as ferritin, lactoferrin, albumin, and ceruloplasmin that sequester free iron and copper ions, that are capable of catalyzing oxidative reactions and numerous other antioxidant phytonutrients present in a wide variety of plant foods. Plants have provided themselves as a potential source of Antioxidants. The plant constituents like phenolics and flavonoids are recognized free radical scavengers. Synthetic antioxidants have been suspected to cause negative health effects. Therefore, their use has been put under scanner and ways are being devised to substitute them with naturally occurring antioxidants ${ }^{2}$.

Narcicuss tazetta is a flowering plant belonging to family Amaryllidaceae and is reported to possesse anti-malarial ${ }^{3}$, anti-inflammatory ${ }^{4}$ anti-cholineserase ${ }^{5}$, anti-viral properties $^{6}$.
Nymphaea mexicana is a flowering aquatic plant belonging to Nymphaeceae, Nymphaea species are reported to posesse anti-inflammatory and anti-diabetic properties ${ }^{7}$, plants of Nymphaea species are recognized to be larvicidal ${ }^{8}$, sedative ${ }^{9}$, anti-microbial 8,10, aphrodhisiac ${ }^{11}$, , anti-hyperlipedemic ${ }^{12}$ etc.

Indigofera heterantha belonging to family fabaceae is reported to help stomachache and Diarhoea ${ }^{13}$, It is used in renal disorders ${ }^{14}$ and is used as Anti-Diabetic and in Toothache ${ }^{15}$

Plants (herbal medicines) have remained an effective and diverse source of drugs since prehistoric times ${ }^{16}$. They have been used to treat various ailments since times immemorial17. The knowledge of Materia Medica for pharmacotherapy for years has been utilized and Herbal drugs have earned significance and popularity over the years for their efficacies and cost effectiveness ${ }^{18}$.

\section{MATERIAL AND METHOD}

\section{Plant material:}

Narcicuss tazetta was collected from Kashmir University Botanical Garden. The curator of Center for Biodiversity \& Taxonomy (CBT) identified the plant vides voucher no. 2608(KASH) Herbarium, CBT. The plant was cleared of dirt and debris. Bulbs were obtained without adventitious roots. The bulbs were then shade dried. 
Nymphaea mexicana flowers were collected from Nigeen lake. The said flowers were identified by curator CBT vide voucher no. 2609 -(KASH) Herbarium, CBT. Cleaned flowers were then shade dried.

Indigofera heterantha was obtained from Drang, Tangmarg. The plant was identified by curator CBT vide voucher no. 2607-(KASH) Herbarium. The plant roots were cleaned, and then shade dried.

\section{Extraction procedure:}

All the extracts of plants were made by cold maceration technique using methanol. $250 \mathrm{~g}$ each of $N$. tazetta bulbs, $N$. mexicana flowers and I. heterantha roots were macerated separately in three maceration bottles using methanol as solvent of extraction in the ratio 1:3. After repeated washings finally, the obtained liquid crude extract was subjected to drying to obtain dry extract. Dessicator was used for final drying.

\section{Qualitative Phytochemical tests:}

A stock concentration of $1 \%(\mathrm{~W} / \mathrm{V})$ of each extract was prepared by using methanol as solvent. These extracts were tested for the presence of active phytochemicals viz: tannins, alkaloids, phytosterols, triterpenoids, flavonoids, cardiac glycosides, anthraquinone glycosides, saponins, carbohydrates, proteins, amino acids, fixed oils \& fats following standard methods 19,20 :

\section{Alkaloids}

$5 \mathrm{mg}$ of extract were dissolved in $5 \mathrm{ml}$ of distilled water. $2 \mathrm{M}$ HCL was further added until an acid reaction occurred and filtered. The filtrate was tested for the presence of alkaloids by following tests.

a. Dragendorff's Test: To $2 \mathrm{ml}$ of the filtrate, added $1 \mathrm{ml}$ of Dragendorff's reagent along the side of the test tube. Formation of orange or orange reddish brown precipitate indicated presence of Alkaloids.

b. Hager's Test: A drop or two of Hager's reagent were added to $1 \mathrm{ml}$ of test solution. The formation of yellow precipitate indicated the presence of alkaloids.

c. Wagner Test: Two drops of Wagner's reagent were added to $1 \mathrm{ml}$ of the test solution along the side of the test tube. The formation of yellow or brown precipitate confirmed the presence of alkaloids.

\section{Tannins}

a. Ferric Chloride Test: To $2 \mathrm{ml}$ of the test solution added a few drops of $5 \%$ ferric chloride solution. Formation of blue color indicated the presence of hydrolysable tannins.

b. Gelatin Test: Added five drops of $1 \%$ gelatin containing $10 \%$ sodium chloride to $1 \mathrm{ml}$ of the test solution. Formation of white precipitates confirmed presence of tannins.

\section{Phytosterols}

Liebermann-Burchard's Test: 2 mg extract was dissolved in $2 \mathrm{ml}$ of acetic anhydride, heated to boiling, cooled and then $1 \mathrm{ml}$ of concentrated sulfuric acid was added along the sides of the test tube. A brown ring formation at the junction and the turning of the upper layer to dark green color confirmed the test positive for the presence of phytosterols.

\section{Triterpenoids}

Salkowski Test: $2 \mathrm{mg}$ of dry extract was shaken with $1 \mathrm{ml}$ of chloroform and few drops of concentrated sulfuric acid were added along the sides of the test tube. A red brown color formed at the interface indicated the presence of triterpenoids.

\section{Flavonoids}

a. Shinoda test: 5 drops of concentrated hydrochloric acid and few magnesium turnings were added drop wise to 1 ml test solution. A pink, scarlet, crimson red or occasionally green to blue color appeared after few minutes. This confirmed the presence of flavonoids.

b. Alkaline reagent test: Addition of 5 drops of $5 \%$ sodium hydroxide to $1 \mathrm{ml}$ of the test solution resulted an increase in the intensity of the yellow color which became colorless on addition of few drops of $2 \mathrm{M}$ hydrochloric acid which indicated the presence of flavonoids.

c. Lead Acetate Test: To $1 \mathrm{ml}$ of the test solution added few drops of $10 \%$ lead acetate, formation of yellow precipitate confirmed the presence of flavonoids.

\section{Saponins}

a. Foam Test: $5 \mathrm{ml}$ of the test solution in a test tube was shaken well for five minutes. Formation of stable foam confirmed the presence of saponins.

b. Olive Oil Test: Few drops of olive oil were added to $2 \mathrm{ml}$ of the test solution and shaken well. The formation of a soluble emulsion confirmed the presence of saponins.

\section{Cardiac Glycosides}

\section{Keller -Killiani Test}

Added $0.4 \mathrm{ml}$ of glacial acetic acid and a few drops of $5 \%$ ferric chloride solution to a little of dry extract. Further 0.5 $\mathrm{ml}$ of concentrated sulfuric acid was added along the sides of the test tube carefully. The formation of blue color in acetic acid layer confirmed the test.

\section{Anthraquinone Glycosides}

\section{Hydroxyanthraquinone Test}

Few drops of $10 \%$ potassium hydroxide were added to $1 \mathrm{ml}$ of extract. Red color formation confirmed the test positive for anthraquinone glycosides.

\section{Test for carbohydrates}

a. Molisch's Test: Few drops of $1 \%$ napthol were added to $1 \mathrm{ml}$ of test solution and 2-3 ml concentrated sulfuric acid were added along the sides of test tube. The reddish violet or purple ring formed at the junction of two liquids confirmed the test.

b. Barfoed's Test: $2 \mathrm{ml}$ of the test solution and $2 \mathrm{ml}$ of reagent were mixed \& kept a in boiling water bath for 1 min. Red precipitate formed indicates the presence of monosaccharides.

c. Seliwanoffs Test: $3 \mathrm{ml}$ of Seliwanoffs reagent was added to $1 \mathrm{ml}$ of the test sample and heated on a water bath for one minute. The formation of rose red color confirmed the test positive for carbohydrates.

\section{Test for Proteins}

a. Biuret test: 5 drops of $1 \%$ copper sulphate solution and 2 $\mathrm{ml}$ of $10 \% \mathrm{NaOH}$ were added to $2 \mathrm{ml}$ of the test solution. Mixed thoroughly, formation of purple or violet color confirmed presence of proteins. 


\section{Test for Amino Acids}

a. Millon's Test: Added 5 drops of millons reagent to $1 \mathrm{ml}$ of test solution and heated on a water bath for $10 \mathrm{~min}$, cooled and added $1 \%$ sodium nitrite solution. Appearance of red color confirmed the test positive for amino acids.

b. Xanthoproteic Test: The extracts were treated with few drops of conc. Nitric acid. Formation of yellow colour indicates the presence of proteins.

c. Ninhydrin Test: To the extract, $0.25 \% \mathrm{w} / \mathrm{v}$ ninhydrin reagent was added and boiled for few minutes. Formation of blue colour indicates the presence of amino acid.

Total Phenolic Content estimation 21

Total Phenolic content estimation Principal: The total phenolic content of the extract was determined by the modified Folin-Ciocalteu method

Preparation of Standard: $50 \mathrm{mg}$ Gallic acid was dissolved in $50 \mathrm{ml}$ methanol, various aliquots of $25-125 \mu \mathrm{g} / \mathrm{ml}$ was prepared in methanol.

Preparation of Extract: $10 \mathrm{mg}$ of dried extract dissolved in $10 \mathrm{ml}$ methanol and filter. $200 \mu \mathrm{L}(1 \mathrm{mg} / \mathrm{ml})$ of this extract was for the estimation of phenols.

Procedure: Briefly, $200 \mu \mathrm{L}$ of extract $(1 \mathrm{mg} / \mathrm{mL})$ were made up to $3 \mathrm{~mL}$ with distilled water, mixed thoroughly with 0.5 $\mathrm{mL}$ of Folin-Ciocalteu reagent for $3 \mathrm{~min}$, followed by the addition of $2 \mathrm{~mL}$ of $20 \%(\mathrm{w} / \mathrm{v})$ sodium carbonate. The mixture was allowed to stand further for $60 \mathrm{~min}$ in the dark, and absorbance was measured at $650 \mathrm{~nm}$. The total phenolic content was calculated from the calibration curve, and the results were expressed as $\mathrm{mg}$ of gallic acid equivalent per $\mathrm{g}$ dry weight.

Total flavonoids content estimation ${ }^{22}$ :

Principal: Determination of total flavonoids content was based on aluminum chloride method .

Preparation of standard: $50 \mathrm{mg}$ rutin was dissolved in 50 $\mathrm{ml}$ methanol, and various aliquots of $25-125 \mu \mathrm{g} / \mathrm{ml}$ were prepared in methanol.
Preparation of extract: $10 \mathrm{mg}$ of extract dissolved in $10 \mathrm{ml}$ methanol and filter. Three $(1 \mathrm{mg} / \mathrm{ml})$ of this extract was for the estimation of flavonoid. $3 \mathrm{ml}$ of extract or standard and allowed to stand for $15 \mathrm{~min}$ at room temperature; absorbance was measured at $510 \mathrm{~nm}$.

In-Vitro free radical scavenging activity (2, 2-diphenyl-1picrylhydrazyl - DPPH) ${ }^{23}$ :

When a solution of DPPH is mixed with that of a substance that can donate a hydrogen atom, then this gives rise to the reduced form with the loss of this violet color.

The free radical scavenging capacity or electron donating ability of different extracts was determined using DPPH. DPPH solution $(0.1 \mathrm{mM})$ was freshly prepared in $95 \%$ ethanol. Different concentrations $(200 \mu \mathrm{g} / \mathrm{ml}-600 \mu \mathrm{g} / \mathrm{ml})$ of methanolic extracts were prepared. $0.1 \mathrm{ml}$ of the various concentrations of above mentioned extracts were mixed with $1.0 \mathrm{ml}$ of DPPH solution.

The reaction mixture was incubated in dark for $30 \mathrm{~min}$. The absorbance was measured at $517 \mathrm{~nm}$. Ascorbic acid was used as a standard $(1 \mathrm{mg} / \mathrm{ml})$. The scavenging capacity of ascorbic acid with distilled water was also measured. Control was prepared in the same way except for the replacement of the test sample with corresponding extraction solvent. All the tests were performed in triplicate.

The scavenging ability of the plant extracts and ascorbic acid was calculated using this equation:

DPPHScavengingactivity $(\%)=\frac{[(\text { Abs. C }- \text { Abs.S })]}{(\text { Abs. C })} \times 100$

Where, Abs. C is the absorbance of DPPH + methanol;

Abs. $\mathrm{S}$ is the absorbance of DPPH radical + sample (i.e. extract or standard).

\section{RESULTS AND DISCUSSION}

\section{Yield of Plant extracts:}

After successful cold extraction the extract was subjected to drying using water bath and dessicator was used for final drying. The yields of extracts from all of the plants are enlisted in Table 1.

Table 1: Comparative yield of Plant extracts

\begin{tabular}{|c|c|c|}
\hline Test Plant & Mass Taken (grams) & Extract Yield (grams) \\
\hline Narcissus tazetta & 250 & 13 \\
\hline Nymphaea mexicana & 250 & 26 \\
\hline Indigofera heterantha & 250 & 32 \\
\hline
\end{tabular}

A portion of these extracts was subjected to various phytochemical tests for presence of different phytoconstituents. The outcome of the qualitative tests is enlisted in Table 2. 
Table 2: Qualitative phytochemical tests

\begin{tabular}{|c|c|c|c|c|}
\hline \multirow{2}{*}{ S.No } & \multirow{2}{*}{ Phytochemical Tests } & \multicolumn{3}{|c|}{ Extract } \\
\hline & & N. tazetta & N.mexicana & I.heterantha \\
\hline \multirow{4}{*}{1} & \multicolumn{4}{|c|}{ Test for Alkaloids } \\
\hline & Drangendroffs test & + & + & + \\
\hline & Hagers test & + & + & + \\
\hline & Wagners test & + & + & + \\
\hline \multirow{2}{*}{2} & \multicolumn{4}{|c|}{ Test for triterpenoids } \\
\hline & Salkowski test & + & + & + \\
\hline \multirow{2}{*}{3} & \multicolumn{4}{|c|}{ Test for phytosterols } \\
\hline & Libermann Buchard's test & - & + & - \\
\hline 4 & \multicolumn{4}{|c|}{ Flavonoids } \\
\hline \multirow{6}{*}{5} & Shinoda test & + & + & + \\
\hline & Alkaline reagent test & + & + & + \\
\hline & Lead acetate test & + & + & + \\
\hline & \multicolumn{4}{|c|}{ Test for saponins } \\
\hline & Foam test & + & - & + \\
\hline & Olive oil stain test & - & - & + \\
\hline \multirow{3}{*}{6} & \multicolumn{4}{|c|}{ Test for Glycosides } \\
\hline & Keller killani test & + & + & + \\
\hline & Test for anthraquinone glycosidses & + & + & + \\
\hline \multirow{2}{*}{7} & \multicolumn{4}{|c|}{ Test for proteins } \\
\hline & Biuret test & + & - & - \\
\hline \multirow{4}{*}{8} & \multicolumn{4}{|c|}{ Test for Amino acids } \\
\hline & Millons test & + & - & - \\
\hline & Ninhydrin test & - & + & - \\
\hline & Xanthoproteic test & + & + & + \\
\hline \multirow{4}{*}{9} & \multicolumn{4}{|c|}{ Test for carbohydrates } \\
\hline & Molishs test & + & + & + \\
\hline & Barfoeds test & + & + & + \\
\hline & Seliwanoffs test & + & + & - \\
\hline 10 & Tannins & + & + & + \\
\hline
\end{tabular}

All the three plant extracts exhibited presence of various phytoconstituents like carbohydrates, flavonoids, glycosides, tannins, terpenoids, alkaloids, phenols etc.

The content of total phenolic content (TPC) was expressed as $\mathrm{mg} / \mathrm{g}$ of gallic acid equivalent of dry extract sample using the equation obtained from the calibration curve: $y=0.009 x+0.0559 R^{2}=0.9818$, where, $x$ is the Gallic acid equivalent (GAE) and $\mathrm{Y}$ is the absorbance.

Total flavonoids content was calculated as rutin equivalent (mg/g) using the equation based on the calibration curve: $\mathbf{y}=0.0099 x+0.0499 R^{2}=0.9281$, where $X$ is the rutin equivalent (RuE) and $\mathrm{Y}$ is the absorbance. The results are given in Table 3.

Table 3: Total phenolics and flavonoids content

\begin{tabular}{|l|c|c|}
\hline \multirow{2}{*}{ Test plant } & \multicolumn{2}{|c|}{$\begin{array}{c}\text { Total phytochemical extract } \\
\text { mg/g }\end{array}$} \\
\cline { 2 - 3 } & Total Phenolics (GAE) & Total Flavonoids (RUE) \\
\hline Narcissus tazetta & $407 \pm 0.05$ & $27 \pm 0.04$ \\
\hline Nymphaea mexicana & $424 \pm 0.04$ & $66 \pm 0.03$ \\
\hline Indigofera heterantha & $342 \pm 0.09$ & $89 \pm 0.06$ \\
\hline
\end{tabular}

Table 4: DPPH scavenging Assay

\begin{tabular}{|c|c|c|c|}
\hline \multirow{2}{*}{ Substrate } & \multicolumn{3}{|c|}{ DPPH \% inhibition (0.1 mM DPPH) } \\
\hline & $200 \mu \mathrm{g} / \mathrm{ml}$ & $400 \mu \mathrm{g} / \mathrm{ml}$ & $600 \mu \mathrm{g} / \mathrm{ml}$ \\
\hline Narcissus tazetta & $21.3 \pm 0.5$ & $42.2 \pm 2.3$ & $62.1 \pm 0.43$ \\
\hline Nymphaea Mexicana & $41.9 \pm 1.5$ & $65.9 \pm 2.2$ & $71.6 \pm 0.1$ \\
\hline Indigofera heterantha & $48.5 \pm 0.1$ & $66.4 \pm 0.2$ & $79.2 \pm 0.1$ \\
\hline Ascorbic Acid & $64.5 \pm 0.6$ & $73.6 \pm 0.3$ & $91.9 \pm 0.3$ \\
\hline
\end{tabular}




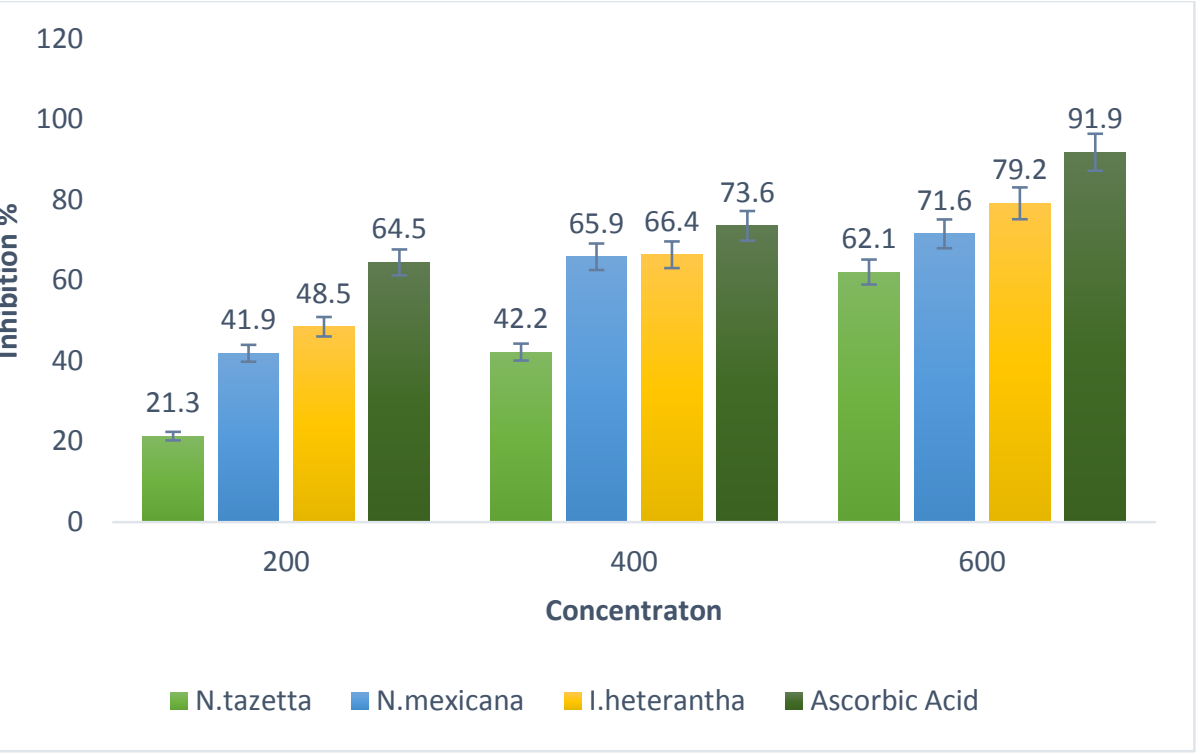

Figure 1: Bar Graph of in vitro free radical scavenging activity

DPPH scavenging assay is mostly accepted invitro assay protocol to evaluate antioxidant potential of substances. With increase in concentration decrease in absorbance was observed. $\mathrm{IC}_{50}$ value for standard was found to be 131.1 $\mu \mathrm{g} / \mathrm{ml}$, Nymphaea mexicana as $296.09 \mu \mathrm{g} / \mathrm{ml}$, Narcicuss tazetta as $479.73 \mu \mathrm{g} / \mathrm{ml}$ and Indigofera heterantha as 208.60 $\mu \mathrm{g} / \mathrm{ml}$. thus the antioxidant activity of all extracts was lesser than standard.

Disruption of balance between antioxidants and ROS due to either exhaustion of antioxidants or building up of ROS causes oxidative stress. Detoxification of reactive oxygen species is essential to the survival of all aerobic life forms. Thus, exploring newer sources of antioxidants is gaining importance increasingly. Antioxidants protect against neurological, cardiovascular, and various other metabolic disorders.

\section{CONCLUSION}

All the extracts have shown presence of various phytoconstituents and all these plant constituents can be positively exploited to be used as treatment strategies against different diseases. Carbohydrates, alkaloids, glycosides, flavonoids etc. were found in the extracts. Total phenolic contents of Narcicuss tazetta bulb, Nymphaea mexicana flower and Indigofera heterantha roots were respectively 15, 6 and 4 times than corresponding flavonoid contents indicating an average of 6.5 times more phenolics than flavonoids in test plant extracts. In fact, mean yield of phenolics did not significantly differ between Narcicuss tazetta bulbs and Nymphaea mexicana flowers while both exhibited significantly more phenolic content than that found in Indigofera heterantha roots.

The mean flavonoid content of Indigofera heterantha roots was not different from that of Nymphaea mexicana flowers while that of Narcicuss tazettas was significantly lower than those of other two plant extracts. In this study this is evident that all the extracts are potent source of bioactive molecules.

\section{REFERENCES}

1. Singh M, Clark W M. "Partitioning of vancomycin using poly (ethylene glycol)- coupled ligands in aqueous two phase systems,." Biotechnol. Progr., Washington (1994): 503- 512.

2. Chandra., Jeewan Singh Jalal and Satish. ". Medicinal plants used in the cur of stomach disorders in Kumaon Himalaya, Uttarakhand, India." Academia J. of Medicinal Plants (2013): 116-121.
3. Sener, Bilge \& Erdogan Orhan, Ilkay \& Satayavivad, Jutamad. "Antimalarial Activity Screening of Some Alkaloids and the Plant Extracts from Amaryllidaceae." Phytotherapy research (2004):1220-3

4. Maryam Rameshk, Fariba Sharififar,Mitra Mehrabani,Abbas Pardakhty,Alireza Farsinejad. "In vitro Proliferation and Wound Healing Effects of Narcissus tazetta L. Bulb on Primary Human Dermal Fibroblasts." Journal of Pharmaceutical Research International (2017): 1-13.

5. López, Susana \& Bastida, Jaume \& Francesc, Viladomat \& Codina, Carles. "Acetylcholinesterase activity of some Amaryllidaceae alkaloids and Narcissus extracts." Life sciences (2002): 2521-2529.

6. Linda S.M. Ooi a, Li Tian a,b,c, Miaoxian Su a, Wing-Shan Ho a, Samuel S.M. Sun aHau-Yin Chung a, Henry N.C. Wong d, Vincent E.C. Ooi. "Isolation, characterization, molecular cloning and modelingof a new lipid transfer protein with antiviral andantiproliferative activities from Narcissus tazetta." Elsevier (2008): 2101-2109.

7. SHOBA, MABEL PARIMALA AND FRANCIS GRICILDA. "EVALUATION OF ANTIDIABETIC POTENTIAL OF NYMPHAEA NOUCHALI BURM. F. SEEDS INSTZ - INDUCED DIABETIC RATS." International Journal of Pharmacy and Pharmaceutical Sciences (2014): 536-541.

8. O. Oladimeji, H \& M. Ubulom, P \& I. Akpabio, E \& E. Etim, I \& Nyong, E. "Larvicidal and AntiMicrobial Potentials of Nymphaea odorata." Journal of Pharmacology and Toxicology (2008): 357362.

9. Mohan Maruga Raja, Muthu Kumaradoss \& Sethiya, Neeraj \& Mishra, Shrihari. "A comprehensive review on Nymphaea stellata: A traditionally used bitter." Journal of advanced pharmaceutical technology \& research (2010): 311-319.

10. O. J Akinjogunla, A. A Adegoke, I. P Udokang and B. C AdebayoTayo. "Antimicrobial potential of Nymphaea lotus(Nymphaeaceae) against wound pathogens." Journal of Medicinal Plants Research (2009): 138-141.

11. Lakhshmi T, Madhusudhanan N.,Rajendran R. "Nymphaea alba Linn. an overview." Research journal of Pharmacy and Technology (2013):974-977.

12. Jaya Raju, B. Satya Vani, G. Santhi , L. Lavanya and T. Chandi Vishala. "EVALUATION OF ANTIHYPERLIPIDEMIC ACTIVITY OF NYMPHAEA ALBA." International Journal of Pharmaceutical Sciences And Research (2016).

13. Muhammad Shoaib Amjad, Muhammad Arshad. "Ethnobotanical inventory and medicinal uses of some important woody plant species of Kotli, Azad." Asian Pacific Journal of Tropical Biomedicine (2014): 952-958.

14. Muhammad Hamayun, Sumera Afzal and Mir Ajab Khan. "Ethnopharmacology, indigenous collection and preservation techniques of some frequently used medicinal plants of utror and gabral, district swat, Pakistan." Afr. J. Traditional (2006): 57-73. 
15. Muhammad Aurang Zeb, Muhammad Sajid, Taj Ur Rahman, Khanzadi Fatima Khattak, Muhammad Tariq Khan.

"Phytochemical screening, anti-diabetic and antioxidant potential of methanolic extract of Indigofera heterantha roots ." International Journal of Biosciences (2017): 255-260.

16. Tiwari, Sudhanshu. "Plants: A Rich Source of Herbal Medicine." Journal of Natural Products, (2008): 27-35.

17. Akinyemi, K. O., Oladapo, O., Okwara, C. E., Ibe, C. C., Fasure, K. A. ". Screening of crude extracts of six medicinal plants used in South-West Nigerian unorthodox medicine for anti-methicillin resistant Staphylococcus aureus activity. ." BMC Complement Alternative medicine (2005): 5-6.

18. Fabio Firenzouli, Luigi Gori. "Herbal Medicine Today: Clinical and Research Issues." Evidence Based Complementary and Alternative Medicine (2007): 37-40.
19. JB, Harbone. Phytochemical method, A guide to Modern technique of plant analysis. New York: Chapman and Hall, 1998.

20. Kokate, C.K. A Textbook Of Practical Pharmacognosy. New Delhi: Vallabh Prakashan, 2005.

21. C. Kaur, H.C. Kapoor,. "Anti-oxidant activity and total phenoliccontent of some Asian vegetables." Int. J. Food Sci. Technol. (2002): 153-161.

22. C. Chang, M. Yang, H. Wen, J. Chern. " Estimation of totalflavonoid content in propolis by two complementary colorimetricmethods." Journal of Food and Drug Analysis (2002): 178-182.

23. Braca A, Tommassi ND, Bari LD, PizzaC. "Antioxidant principles from Bauhinia terapotensis." Journal of Natural Products. (2001): 892-895 